\title{
Determination of COVID-19 Patients Using Machine Learning Algorithms
}

\author{
Marium Malik ${ }^{1}$, Muhammad Waseem Iqbal ${ }^{1, *}$, Syed Khuram Shahzad ${ }^{2}$, Muhammad \\ Tahir Mushtaq ${ }^{2}$, Muhammad Raza Naqvi ${ }^{3,4}$, Maira Kamran ${ }^{1}$, Babar Ayub Khan ${ }^{4}$ and Muhammad \\ Usman Tahir ${ }^{4}$
}

\author{
${ }^{1}$ Department of Software Engineering, The Superior College, Lahore, 54000, Pakistan \\ ${ }^{2}$ Department of Informatics and Systems, University of Management and Technology, Lahore, 54000, Pakistan \\ ${ }^{3}$ INP-ENIT, University of Toulouse, 65000 , France \\ ${ }^{4}$ Department of Computer Science, The Superior College, Lahore, 54000, Pakistan \\ ${ }^{*}$ Corresponding Author: Muhammad Waseem Iqbal. Email: waseem.iqbal@superior.edu.pk \\ Received: 20 March 2021; Accepted: 18 May 2021
}

\begin{abstract}
Coronavirus disease (COVID-19), also known as Severe acute respiratory syndrome (SARS-COV2) and it has imposed deep concern on public health globally. Based on its fast-spreading breakout among the people exposed to the wet animal market in Wuhan city of China, the city was indicated as its origin. The symptoms, reactions, and the rate of recovery shown in the coronavirus cases worldwide have been varied. The number of patients is still rising exponentially, and some countries are now battling the third wave. Since the most effective treatment of this disease has not been discovered so far, early detection of potential COVID-19 patients can help isolate them socially to decrease the spread and flatten the curve. In this study, we explore state-of-the-art research on coronavirus disease to determine the impact of this illness among various age groups. Moreover, we analyze the performance of the Decision tree (DT), K-nearest neighbors $(\mathrm{KNN})$, Naïve bayes (NB), Support vector machine (SVM), and Logistic regression (LR) to determine COVID-19 in the patients based on their symptoms. A dataset obtained from a public repository was collected and pre-processed, before applying the selected Machine learning (ML) algorithms on them. The results demonstrate that all the ML algorithms incorporated perform well in determining COVID-19 in potential patients. NB and DT classifiers show the best performance with an accuracy of $93.70 \%$, whereas other algorithms, such as SVM, KNN, and LR, demonstrate an accuracy of $93.60 \%, 93.50 \%$, and $92.80 \%$ respectively. Hence, we determine that ML models have a significant role in detecting COVID-19 in patients based on their symptoms.
\end{abstract}

Keywords: Coronavirus; machine learning; naïve bayes; decision tree; disease analysis

This work is licensed under a Creative Commons Attribution 4.0 International License, which permits unrestricted use, distribution, and reproduction in any medium, provided the original work is properly cited. 


\section{Introduction}

The COVID-19 is a harmful and detrimental illness impacting the entire world. The earliest cases were found in a city named Wuhan of China, in the last week of December 2019, followed by a rapid spread globally. Most people infected by this disease undergo moderate treatment to reduce respiratory illness and improve without needing a specific method. The COVID-19 virus develops substantially from droplets of saliva and the release of the nose, and it spreads from individual to individual [1]. Even after more than a year of the generation of this disease, the most effective treatment have not been successfully launched. However, various continuous clinical experiments are assessing the best possible approaches of cure, and vaccinations are developed. Since the vaccines are not yet mature, other techniques like early detection of the disease can be effective to decrease the spread. Artificial intelligence (AI) approaches, including machine learning approaches [2] and deep learning algorithms [3], play an essential role in prediction for this disease like outbreak prediction [4,5], high-risk patients' identification [6], COVID-19 analysis with clinical features [7], spread probability analysis [8], ways to combat this disease [9], and death risk in patients. The recent advancement in AI and data mining approaches to solve medical problems emphasize that they can improve the epidemic situation [10]. Mohamad et al. [11] developed a system that showed high accuracy in predicting the life risk of patients based on physiological conditions, symptoms, and demographics. Allae et al. [12] predicted the threshold of COVID-19 cases in a region by generating a ML model. Ardabili et al. [13] suggested that amalgamation of ML models and soft computing models can help predict outbreaks. Old-aged people, especially the ones with underlying illnesses like cardiovascular disorder, diabetes, persistent lung infection, and cancer are witnessed to be primarily harmed by this severe disease. Additionally, there are now signs that the demographics and profile of patients passing in China or one part of the world may not be equivalent to that in the other parts of the world, so it is valuable for individuals of any age to take extraordinary safety measures.

Machine learning is playing a vital role in multiple areas that were previously thought to be only humancentric tasks. They are utilized to integrate heterogeneous biomedical data sources to generate predictive models using data of symptoms obtained from clinical test data. This research aims to determine how accurately a COVID-19 positive patient can be identified based on their symptoms. The main objective of our research is to analyze the performance of supervised machine learning algorithms, including DT, KNN, $\mathrm{NB}, \mathrm{LR}$, and SVM, by examining their classification reports to determine the best performing algorithm.

\section{Symptoms of Coronavirus}

In most cases, the signs of COVID-19 emerge after an incubation span of nearly 5.2 days [14]. Whereas, it has been observed that the entire span of the disease ranges between 6 to 41 days, with an average of around two weeks. It has been observed that the containment span of the disease is proportional to the age and immunity strength of the patient. Fig. 1 shows the most common symptoms found in coronavirus patients. In the COVID-19 cases, the patients show distinct signs during the incubation period or soon after that. The prevalent symptoms reported of the disease are as follows [15]:

\subsection{Most Common Symptoms}

The most common symptoms felt by potential patients are Fever, Cough, and Fatigue.

\subsection{Other Less Common Symptoms}

In some cases, the potential patients showed signs such as production of Sputum, Headache, Hemoptysis, Diarrhea, Dyspnea, and Lymphopenia. 


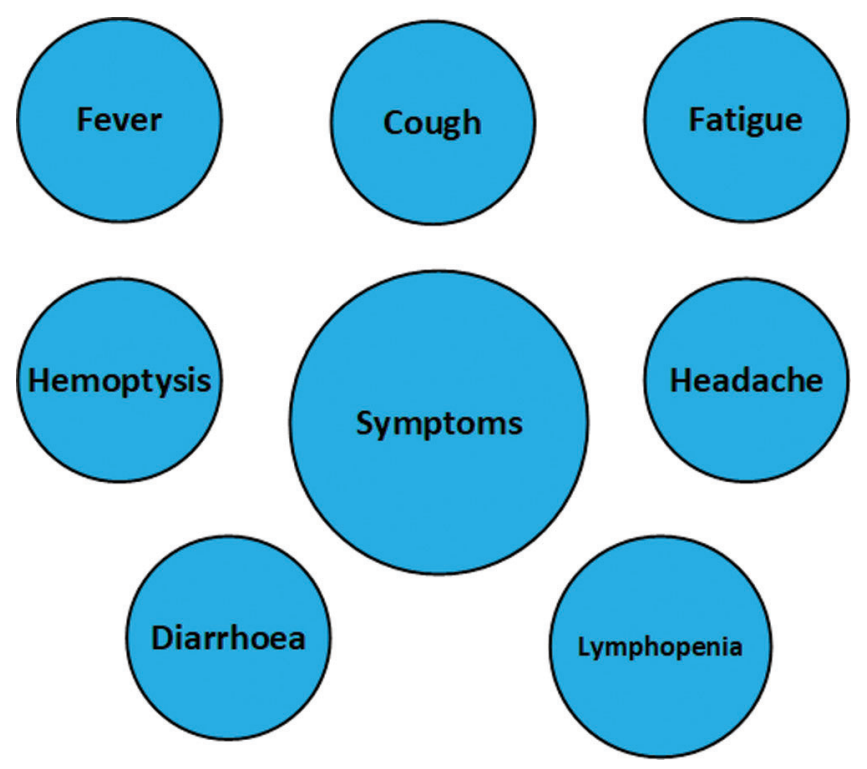

Figure 1: Symptoms of COVID-19

\section{Literature Review}

The previous studies, examinations, or experiments to combat this severe infection are numerous and still being counted. A prominent method to regulate coronavirus toxicities is through drug administration [16]. A total of 80 cases, tested positive COVID-19 were analyzed and characterized concerning the World health organization (WHO) guidelines in grade 3 hospitals located in Jiangsu. The discovery of the disease in the respiratory trials was conducted with the help of a Reverse stranscription-polymerase chain reaction (RT-PCR). Among the total 80 patients, the number of female subjects was 41 , with an average age of 46.1 years [17].

It was observed that 77 patients were mildly infected, and 3 were severely ill. A total of 38 subjects had a history of persistent diseases. 63 subjects reported symptoms of fever, and 51 subjects showed signs of cough. Observation of the patient's lung images demonstrated atypical shadows on 55 patients' scans, whereas 25 had no shade. No deaths were reported in the scenario, and the number of patients discharged within 8 days was 21 . Hence it is seen that the cases in Jiangsu were mild as compared to that of Wuhan in terms of effects such as liver dysfunction and atypical activities in the lungs [18].

According to clinical information from $13^{\text {th }}$ January till $19^{\text {th }}$ February 2020, there were 28 COVID-19 patients infected in Wuhan city. In infected patients, $60.7 \%$ are male, and their age was around 65 years [19]. Seven investigations were analyzed for meta-examination. The outcomes demonstrated that the most predominant clinic manifestations were fever $91.3 \%$, weariness $51.0 \%$, and dyspnea $30.4 \%$ [20].

Zunyou et al. summarized the key points from a significant publication by the Chinese centre comprising a report of 72,314 cases. Of these, 44,672 were confirmed cases, 16,186 were suspected cases, and 10,567 were diagnosed based on symptoms, and 889 were asymptomatic. About $87 \%$ of the patients were aged 30 to 79 , which shows that coronavirus affects older people more than younger ones [21]. In the same league, Heshui shi et al. presented a study to describe the CT scans of 81 patients and determined that a combined examination of imaging features and clinical data can help in the early diagnosis of COVID-19 disease [22]. A couple of applicants have indicated viability in vitro investigations, and not many have advanced to a randomized creature or human preliminaries, subsequently may have restricted use to counter COVID-19 contamination [23]. Ying et al. [24] analyzed 
the reproduction number $\left(R_{0}\right)$ that points out the transmissibility of the disease from one person to another person. The results showed that the value of $R_{0}$ is substantially higher than the value estimated by WHO.

Qiurong ruan et al. conducted a multicenter study of 68 deaths and 82 discharged reports of COVID-19 diagnosed patients. They concluded that fatal outcome was observed in cases of older people with the presence of secondary infections and increased inflammatory indicators in the blood. They also stated that the risk of mortality is higher in cases of cytokine storm syndrome [25]. Neurological side effects fall into three classes: focal sensory system that is the side effects of Central nervous system (CNS), ailments (migraine, discombobulation, disabled awareness, ataxia, intense cerebrovascular infection, and epilepsy), and fringe sensory system, peripheral nervous system (PNS) side and skeletal muscle injury [26].

It is determined that RT-PCR testing is the most practical and efficient diagnosis test for COVID-19 determination, but Chest CT scan analysis is also a competent diagnosis method. For comparing the diagnostic value and consistency, Tao et al. [27] conducted a study and the results showed that Chest CT scans are highly sensitive for COVID-19 detection and can be used as the main tool. Analysis of symptoms and patients' history shows that COVID-19 spreads through direct contact [28]. Although the cases reported in Jiangsu are comparatively moderate as compared with Wuhan [29].

Detection of COVID-19 carriers is critically important because, with an absence of a potential vaccine, only effective method to cope with spread of this disease is by detecting the potentially infected people and isolating them from healthy people [30]. Mizner et al. [31] presented a review of the existing detection methods showing that each method has its shortcoming, hence amore efficient system needs to be created.

Prabira et al. analyzed 11 different Convolutional neural networks (CNN) systems and suggested an accurate support vector framework that incorporates SVM with classification models like Residual neural network (ResNet50) to the class of patients showing signs of coronavirus from X-Ray scans of potential sufferers. The ResNet50 plus model showed higher accuracy on the data that they obtained from multiple online data repositories [32].

Tab. 1 shows the state-of-the-art research conducted to identify the symptoms, gender, age, number of days the patient remained infected, additional diseases the patient was undergoing corresponding to the country, and city where the patient was monitored.

Table 1: Patient details and symptoms

\begin{tabular}{|c|c|c|c|c|c|c|c|c|c|}
\hline $\mathrm{Sr} \#$ & $\begin{array}{l}\text { Year/ } \\
\text { Month }\end{array}$ & Author & $\begin{array}{l}\text { Number of } \\
\text { Cases }\end{array}$ & $\begin{array}{l}\text { Additional } \\
\text { Disease }\end{array}$ & $\begin{array}{l}\text { Death/Recovery } \\
\text { Rate }\end{array}$ & $\begin{array}{l}\text { Days } \\
\text { Infected }\end{array}$ & $\begin{array}{l}\text { Country and } \\
\text { City }\end{array}$ & $\begin{array}{l}\text { Gender and } \\
\text { Age Group }\end{array}$ & Symptoms \\
\hline 1 & $\begin{array}{l}\text { Feb } \\
2020\end{array}$ & $\begin{array}{l}\text { Jian } \\
\text { et al. } \\
{[25]}\end{array}$ & 80 & $\begin{array}{l}38 \text { patients with a } \\
\text { history of chronic } \\
\text { disease }\end{array}$ & $23 \%$ recovered & $\begin{array}{l}8 \text { days, } \\
21 \text { patients }\end{array}$ & $\begin{array}{l}\text { Jiangsu, } \\
\text { China }\end{array}$ & $\begin{array}{l}41 \text { females, } \\
\text { average age } \\
46.1 \text { years }\end{array}$ & $\begin{array}{l}\text { Fever and cough in } \\
63 \text { and } 51 \text { cases }\end{array}$ \\
\hline 2 & $\begin{array}{l}\text { March } \\
2020\end{array}$ & $\begin{array}{l}\text { Zhang } \\
\text { et al. } \\
{[15]}\end{array}$ & $18-28$ & Cancer & $\begin{array}{l}28.6 \% \\
\text { recovered }\end{array}$ & 14 days & $\begin{array}{l}\text { Wuhan, } \\
\text { China }\end{array}$ & $\begin{array}{l}17(60.7 \%) \\
\text { male patients, } \\
65 \text { years }\end{array}$ & $\begin{array}{l}\text { Fever, dry cough, } \\
\text { fatigue, and } \\
\text { dyspnea }\end{array}$ \\
\hline 3 & $\begin{array}{l}\text { May } \\
2020\end{array}$ & $\begin{array}{l}\text { J. Yang } \\
\text { et al. } \\
{[16]}\end{array}$ & $\begin{array}{l}77658 \text { included } \\
576 \text { infected } \\
\text { patients }\end{array}$ & $\begin{array}{l}\text { Hypertension, } \\
\text { diabetes, and } \\
\text { cardiovascular } \\
\text { disease }\end{array}$ & 2663 deaths & 17 days & China & $\begin{array}{l}\text { Female } \\
(890: 686), \\
\text { Male (890), } \\
\text { Age (45-57) }\end{array}$ & $\begin{array}{l}\text { Fever, cough, } \\
\text { fatigue, and } \\
\text { dyspnea }\end{array}$ \\
\hline 4 & $\begin{array}{l}\text { April } \\
2020\end{array}$ & $\begin{array}{l}\mathrm{Z} . \mathrm{Wu} \\
\text { et al. } \\
{[17]}\end{array}$ & 72314 & $\begin{array}{l}\text { Asymptomatic } \\
\text { cases with lung } \\
\text { diseases }\end{array}$ & 5 deaths & 30 days & China & $10-80$ years & $\begin{array}{l}\text { Fever, dry cough, } \\
\text { and fatigue }\end{array}$ \\
\hline 5 & $\begin{array}{l}\text { April } \\
2020\end{array}$ & $\begin{array}{l}\text { H. Shi } \\
\text { et al. } \\
{[18]}\end{array}$ & 81 & $\begin{array}{l}\text { Chest CT } \\
\text { imaging } \\
\text { abnormalities }\end{array}$ & $4 \%$ deaths & 10.5 days & China & $\begin{array}{l}42 \text { men, } \\
39 \text { women, } \\
\text { and } 50 \text { years } \\
\text { age }\end{array}$ & $\begin{array}{l}\text { Fever, dry cough, } \\
\text { and fatigue }\end{array}$ \\
\hline
\end{tabular}




\begin{tabular}{|c|c|c|c|c|c|c|c|c|c|}
\hline Sr\# & $\begin{array}{l}\text { Year/ } \\
\text { Month }\end{array}$ & Author & $\begin{array}{l}\text { Number of } \\
\text { Cases }\end{array}$ & $\begin{array}{l}\text { Additional } \\
\text { Disease }\end{array}$ & $\begin{array}{l}\text { Death/Recovery } \\
\text { Rate }\end{array}$ & $\begin{array}{l}\text { Days } \\
\text { Infected }\end{array}$ & $\begin{array}{l}\text { Country and } \\
\text { City }\end{array}$ & $\begin{array}{l}\text { Gender and } \\
\text { Age Group }\end{array}$ & Symptoms \\
\hline 6 & $\begin{array}{l}\text { April } \\
2020\end{array}$ & $\begin{array}{l}\text { Q. Ruan, } \\
\text { K. Yang } \\
\text { et al. } \\
\text { [21] }\end{array}$ & 150 & $\begin{array}{l}\text { Mild flu, } \\
\text { myocardial } \\
\text { damage, and } \\
\text { circulatory failure }\end{array}$ & 68 deaths & 14 days & China & $30-85$ years & $\begin{array}{l}\text { Fever, dry cough, } \\
\text { and fatigue }\end{array}$ \\
\hline 7 & $\begin{array}{l}\text { Feb } \\
2020\end{array}$ & $\begin{array}{l}\text { L. Mao } \\
\text { et al. } \\
\text { [22] }\end{array}$ & 75569 & $\begin{array}{l}\text { Lung CT } \\
\text { abnormalities } \\
\text { (hypogeusia, } \\
\text { hyposmia, } \\
\text { hypoplasia, and } \\
\text { neuralgia) }\end{array}$ & 2239 deaths & 10 days & $\begin{array}{l}\text { China, } \\
\text { Europe, } \\
\text { North } \\
\text { America, } \\
\text { and Asia }\end{array}$ & $\begin{array}{l}52.7 \pm \\
15.5 \text { years } \\
\text { and } 127 \\
(59.3 \%) \\
\text { females }\end{array}$ & $\begin{array}{l}\text { Headache, acute } \\
\text { cerebrovascular, } \\
\text { and } \\
\text { dizziness }\end{array}$ \\
\hline 8 & $\begin{array}{l}\text { Feb } \\
2020\end{array}$ & $\begin{array}{l}\text { T. Ai } \\
\text { et al. } \\
{[23]}\end{array}$ & 77658 & RT-PCR essays & $\begin{array}{l}\text { 2663recovered, } \\
\text { and } 33 \text { deaths }\end{array}$ & 7 days & 33 Countries & $\begin{array}{l}\text { Age, } 51 \pm \\
15 \text { years, } \\
46 \% \text { male }\end{array}$ & $\begin{array}{l}\text { Fever, and dry } \\
\text { cough }\end{array}$ \\
\hline 9 & $\begin{array}{l}\text { April } \\
2020\end{array}$ & $\begin{array}{l}\text { L. Van } \\
\mathrm{Cu} \text { et al. } \\
{[24]}\end{array}$ & 21 infected & $\begin{array}{l}\text { Mild chest pain, } \\
\text { and blood } \\
\text { pressure }\end{array}$ & Some recovered & 5 days & Wuhan & $\begin{array}{l}25 \text { years old } \\
\text { woman }\end{array}$ & $\begin{array}{l}\text { Cough, flu, fever, } \\
\text { and chest pain }\end{array}$ \\
\hline 10 & $\begin{array}{l}\text { Feb } \\
2020\end{array}$ & $\begin{array}{l}\text { J. Wu } \\
\text { et al. } \\
{[25]}\end{array}$ & $\begin{array}{l}66577, \text { China, } \\
80 \text { patients } \\
\text { infected }\end{array}$ & $\begin{array}{l}\text { A syndrome is } \\
\text { known as an } \\
\text { (ARDS) } \\
\text { metabolic } \\
\text { acidosis }\end{array}$ & $\begin{array}{l}21 \text { cases } \\
\text { recovered }\end{array}$ & 8 days & $\begin{array}{l}\text { China, and } \\
\text { other } \\
\text { countries }\end{array}$ & $\begin{array}{l}41 \text { females, } \\
\text { age } 46 \text { years }\end{array}$ & Chest pain or other \\
\hline 11 & $\begin{array}{l}\text { May } \\
2020\end{array}$ & $\begin{array}{l}\text { Z. Hu } \\
\text { et al. } \\
{[26]}\end{array}$ & $\begin{array}{l}51857, \\
24 \text { infected } \\
\text { cases }\end{array}$ & $\begin{array}{l}\text { CT images of } \\
\text { glass chest, } \\
\text { shadow in lungs }\end{array}$ & 1121 deaths & 9.5 days & $\begin{array}{l}\text { Nanjin, } \\
\text { Jiangsu } \\
\text { Province, } \\
\text { China }\end{array}$ & $\begin{array}{l}\text { Males, ages } \\
\text { ranging from } \\
5 \text { to } 95 \text { years }\end{array}$ & $\begin{array}{l}\text { Fever, cough, and } \\
\text { fatigue }\end{array}$ \\
\hline
\end{tabular}

Mohammad et al. proposed a framework to detect coronavirus-based thermal screening of the patients using an Internet of things (IoT) based smart helmet. They reviewed 6 case studies that analyzed COVID-19, infected patients, using qRT-PCR, and CT scan analysis method. The study concludes that the accuracy of qRT-PCR (81.3\%) was lower than the CT scan (89.8\%), therefore the CT scan method is more substantial [33]. It projected an open-source $\mathrm{CNN}$ that uses resizing and recurring learning rate discovery techniques and an altered version of the ResNet50 system which results in $96.23 \%$ accuracy on a public dataset (COVID) with an epoch count of 41 [34].

Ioannis et al. gauged the performance of $\mathrm{CNN}$ framework generated through transfer learning approach to detect several irregularities in small medical image data repositories. The result of analysis on two different datasets showed 96\% accuracy, 98.66\% sensitivity, and 96.46\% specificity [35]. Biraja et al. proposed a framework that trains a bayesian deep learning classifier using transfer method to find out vulnerability in the X-ray scans from an open COVID-19 dataset. The outcome determines that susceptibility results in higher reliability in the estimate as it alarms radiologists on incorrect forecasts [36].

Charmaine et al. summarized that radiographic patterns of observation in CT chest scans and RT-PCR are significant methods for the recognition of coronavirus. Their research is the comparison of $2 \mathrm{D}$, and $3 \mathrm{D}$ deep neural networks which resulted in $0.966 \%$ AUC, 98.2\% sensitivity, and $92.2 \%$ specificity [37].

Bin et al. [38] demonstrated an experiment of Lopinavir-Ritonavir on elderly people hospitalized with severe coronavirus impact which caused breathing hindrance. Ying et al. illustrated that the period was secured from 1 January to 2 February 2020. During the time, they recognized 12 investigations that assessed the essential conceptive number for coronavirus cases from China or abroad. The assessments ranged from 1.4 to 6.49 where the mean calculated was 3.28 , the middle was 2.79 , and the inter-quartile 
was 1.16 [39]. Ganyani et al. [40,41] determined that an essential key irresistible sickness constraint of this disease is quintessential to demonstrate and manage the intercession techniques.

T. Thiruvalluan et al. stated that the coronavirus arising in Wuhan city in China is spreading throughout the world with the ACE II receptor as a binding site via human transmission, and is called SARS CoV-2. It is currently no officially approved cure for COVID-19 that has been controlled by symptomatic relief and some antiviral medication, so avoidance plays an important role in suppressing the spread [42-44].

Akib Mohi et al. state that over 100 countries were affected by COVID-19 in no time. It is important to develop a control system that will detect coronavirus. Disease diagnosis may be one of the remedies for handling the current havoc with the help of various AI resources [45]. Shi Zhao et al. stated that since December 2019, the extreme acute respiratory disease coronavirus (SARS-CoV-2), has exhibited a large spread (COVID-19) in other parts of the world starting from Wuhan, China. As of 15 February, there were 56 COVID-19 confirmed cases in Hong Kong after the onset of the first symptom on 23, 2020 January [46].

The above Tab. 2 shows the previous research conducted to analyze the various methodologies applied to detect coronavirus. The table states the input features utilized in the commonly applied detection methods, the source of data used, classifiers used, and result obtained.

Table 2: Previous methodologies applied to detect coronavirus

\begin{tabular}{|c|c|c|c|c|c|c|c|c|}
\hline $\begin{array}{l}\mathrm{Sr} \\
\#\end{array}$ & $\begin{array}{l}\text { Month/ } \\
\text { Year }\end{array}$ & Author & $\begin{array}{l}\text { Detection } \\
\text { Method }\end{array}$ & $\begin{array}{l}\text { Input } \\
\text { Parameters }\end{array}$ & Data Source & Study Detail & $\begin{array}{l}\text { Classifier } \\
\text { Used }\end{array}$ & Result Obtained \\
\hline 1 & $\begin{array}{l}\text { Feb } \\
2020\end{array}$ & $\begin{array}{l}\text { Minzhe et al. } \\
\text { [31] }\end{array}$ & $\begin{array}{l}\text { Review of an } \\
\text { available } \\
\text { nucleic acid } \\
\text { method for } \\
\text { detecting } \\
\text { coronaviruses, }\end{array}$ & $\begin{array}{l}\text { Segments of } \\
\text { the gene for } \\
\text { PCR based } \\
\text { methods, } \\
\text { DNA, RNA } \\
\text { for lamp, } \\
\text { and Micro } \\
\text { Array }\end{array}$ & $\begin{array}{l}\text { GitHub } \\
\text { Open-i }\end{array}$ & $\begin{array}{l}\text { Analysis of } \\
\text { various } \\
\text { coronavirus } \\
\text { detection } \\
\text { methods }\end{array}$ & $\begin{array}{l}\text { PCR, DNA, } \\
\text { RNA, }\end{array}$ & $\begin{array}{l}\text { Each detection method has } \\
\text { some drawbacks, thus new } \\
\text { methods should be } \\
\text { examined }\end{array}$ \\
\hline 2 & $\begin{array}{l}\text { March } \\
2020\end{array}$ & $\begin{array}{l}\text { Muhammad } \\
\text { et al. [34] }\end{array}$ & $\begin{array}{l}\text { CNN system } \\
\text { by retuning } \\
\text { ResNet- } \\
50 \text { model }\end{array}$ & $\begin{array}{l}\text { Resized } \\
\text { input images }\end{array}$ & $\begin{array}{l}\text { Publicly available } \\
\text { COVID-Net dataset } \\
\text { on GitHub }\end{array}$ & $\begin{array}{l}\text { System is } \\
\text { proposed by } \\
\text { fine-tuning, } \\
\text { ResNet- } 50 \text { for } \\
\text { input size, and } \\
\text { learning rate }\end{array}$ & CNN, ResNet & $\begin{array}{l}\text { The model showed } \\
96.23 \% \text { accuracy on the } \\
\text { COVID- } 19 \text { patient's data } \\
\text { with only } 41 \text { epochs }\end{array}$ \\
\hline 3 & $\begin{array}{l}\text { March } \\
2020\end{array}$ & $\begin{array}{l}\text { Arabia et al. } \\
{[32]}\end{array}$ & $\begin{array}{l}\text { Deep } \\
\text { Learning, } \\
\text { ResNet } \\
50 \text { plus, } \\
\text { For deep } \\
\text { feature } \\
\text { extraction }\end{array}$ & $\mathrm{X}$-ray & $\begin{array}{l}\text { GitHub } \\
\text { Open-i }\end{array}$ & $\begin{array}{l}\text { Selection of } \\
\text { train/validation/ } \\
\text { test ratio: } \\
\text { random 60: } 20 \text { : } \\
20\end{array}$ & SVM & $\begin{array}{l}\mathrm{FPR}=95.38 \% \\
\mathrm{~F} 1=95.52 \% \\
\mathrm{MCC}=91.41 \% \\
\mathrm{Kappa}=90.76 \%\end{array}$ \\
\hline 4 & $\begin{array}{l}\text { March } \\
2020\end{array}$ & $\begin{array}{l}\text { Mohammad } \\
\text { et al. [33] }\end{array}$ & $\begin{array}{l}\text { IoT based } \\
\text { thermal } \\
\text { helmet for } \\
\text { recording } \\
\text { temperature of } \\
\text { subjects }\end{array}$ & $\begin{array}{l}\text { Image } \\
\text { Processing, } \\
\text { IoT, GSM } \\
\text { interference, } \\
\text { GPS and } \\
\text { Mobile } \\
\text { application }\end{array}$ & $\begin{array}{l}\text { GLH to track places } \\
\text { visited by infected }\end{array}$ & $\begin{array}{l}\text { Input source of a } \\
\text { thermal and } \\
\text { optical camera } \\
\text { Microcontroller, } \\
\text { Arduino IDE } \\
\text { Output source }\end{array}$ & $\begin{array}{l}\text { Proteus } \\
\text { software for } \\
\text { the basic } \\
\text { model }\end{array}$ & $\begin{array}{l}\text { Capability to detect the } \\
\text { temperature of the subject } \\
\text { from a distant place in a } \\
\text { crowded location }\end{array}$ \\
\hline
\end{tabular}


IASC, 2022, vol.31, no.1

\begin{tabular}{|c|c|c|c|c|c|c|c|c|}
\hline $\begin{array}{l}\mathrm{Sr} \\
\#\end{array}$ & $\begin{array}{l}\text { Month/ } \\
\text { Year }\end{array}$ & Author & $\begin{array}{l}\text { Detection } \\
\text { Method }\end{array}$ & $\begin{array}{l}\text { Input } \\
\text { Parameters }\end{array}$ & Data Source & Study Detail & $\begin{array}{l}\text { Classifier } \\
\text { Used }\end{array}$ & Result Obtained \\
\hline 5 & $\begin{array}{l}\text { March } \\
2020\end{array}$ & $\begin{array}{l}\text { Biraja et al. } \\
{[36]}\end{array}$ & $\begin{array}{l}\text { Analysis of } \\
\text { dropwort } \\
\text { based } \\
\text { convolutional } \\
\text { neural } \\
\text { network }\end{array}$ & $\begin{array}{l}\text { X-ray } \\
\text { dataset } \\
\text { images }\end{array}$ & $\begin{array}{l}\text { Coronavirus X-ray } \\
\text { of chest dataset to } \\
\text { identify lung } \\
\text { swelling, and } \\
\text { enlargement of } \\
\text { lymph nodes }\end{array}$ & $\begin{array}{l}\text { NN parameters } \\
\text { for independent, } \\
\text { and identical } \\
\text { training samples } \\
\text { to analyze }\end{array}$ & $\begin{array}{l}\text { Bayesian deep } \\
\text { learning } \\
\text { MC drop } \\
\text { weight to } \\
\text { enhance the } \\
\text { accuracy of } \\
\text { predictions }\end{array}$ & $\begin{array}{l}\text { Results depict a correlation } \\
\text { between uncertainty, and } \\
\text { accuracy in prediction }\end{array}$ \\
\hline 6 & $\begin{array}{l}\text { March } \\
2020\end{array}$ & $\begin{array}{l}\text { Binn et al. } \\
{[38]}\end{array}$ & $\begin{array}{l}\text { Adults } \\
\text { hospitalized a } \\
\text { trial with } \\
\text { severe } \\
\text { coronavirus of } \\
\text { Lopinavir } \\
\text { Ritonavir }\end{array}$ & $\begin{array}{l}\text { The clinical, } \\
\text { and } \\
\text { electronic } \\
\text { data set used }\end{array}$ & $\begin{array}{l}\text { Male and non- } \\
\text { pregnant female } \\
\text { patients, } 18 \text { years } \\
\text { old diagnostic } \\
\text { specimen positive } \\
\text { on RT-PCR }\end{array}$ & $\begin{array}{l}\text { clinical recorded } \\
\text { data in the forms } \\
\text { and electronic } \\
\text { entered double } \\
\text { database } \\
\text { validated by trial } \\
\text { staff }\end{array}$ & $\begin{array}{l}\text { Lopinavir } \\
\text { Ritonavir } \\
\text { treatment or } \\
100 \text { to the } \\
\text { standard care } \\
\text { group }\end{array}$ & $\begin{array}{l}\text { Lopinavir in } 13 \text { patients } \\
\text { because of events }\end{array}$ \\
\hline 7 & $\begin{array}{l}\text { March } \\
2020\end{array}$ & $\begin{array}{l}\text { Loannis } \\
\text { et al. [35] }\end{array}$ & $\begin{array}{l}\text { Evaluation of } \\
\text { convolutional } \\
\text { neural } \\
\text { network } \\
\text { architecture }\end{array}$ & $\begin{array}{l}\text { X-ray } \\
\text { images from } \\
\text { cohen } \\
\text { dataset } \\
\text { available on } \\
\text { GitHub }\end{array}$ & $\begin{array}{l}1428 \text { X-ray dataset } \\
\text { confirmed with } \\
24 \text { positive cases, } \\
700 \text { confirmed, } \\
\text { common with } \\
\text { bacterial and } \\
\text { infected cases }\end{array}$ & $\begin{array}{l}\text { CNN model for } \\
\text { spotting a } \\
\text { variety of } \\
\text { abnormalities in } \\
\text { the small image } \\
\text { data repository }\end{array}$ & $\begin{array}{l}\text { Untrainable } \\
\text { layers at the } \\
\text { bottom }\end{array}$ & $\begin{array}{l}\text { Good performance of the } \\
\text { deep learning framework } \\
\text { with } 96.78 \% \text { accuracy, } \\
98.66 \% \text { sensitivity, and } \\
96.46 \% \text { specificity }\end{array}$ \\
\hline 8 & $\begin{array}{l}\text { March } \\
2020\end{array}$ & $\begin{array}{l}\text { Tipwa et al. } \\
\text { [40] }\end{array}$ & $\begin{array}{l}\text { Estimate the } \\
\text { onset } \\
\text { symptom of } \\
\text { data with } \\
\text { generation } \\
\text { interval }\end{array}$ & $\begin{array}{l}\text { Shopping } \\
\text { mall dataset, } \\
\text { Singapore, } \\
\text { and Tianjin. } \\
\text { Data set } \\
\text { available in } \\
\text { GitHub }\end{array}$ & $\begin{array}{l}\text { Dataset of shopping } \\
\text { center } 45 \text { cases, } \\
\text { Singapore } 45 \text { cases }\end{array}$ & $\begin{array}{l}\text { Previous } \\
\text { estimates with } \\
\text { no change so it } \\
\text { does not } \\
\text { distribute the big } \\
\text { impact on } \\
\text { estimates }\end{array}$ & $\begin{array}{l}\text { Dataset of } \\
\text { shopping } \\
\text { center and } \\
\text { Singapore }\end{array}$ & $\begin{array}{l}\text { Singapore, the mean age } \\
\text { was } 5.2 \text { with } 75 \text { days } \\
\text { China } 3-4 \text { days it depends } \\
\text { on the formula of the } \\
\text { brooding period with mean } \\
\text { value } 5.2 \text { in } 2.8 \text { days }\end{array}$ \\
\hline 9 & $\begin{array}{l}\text { April } \\
2020\end{array}$ & $\begin{array}{l}\text { Charmaine } \\
\text { et al. [37] }\end{array}$ & $\begin{array}{l}\text { Deep learning } \\
\text { and CNN } \\
\text { frameworks } \\
\text { analysis for } \\
\text { detection of } \\
\text { COVID-19 }\end{array}$ & CT scans & $\begin{array}{l}618 \text { sloping CT } \\
\text { scans which } \\
\text { included 110/ } \\
219 \text { COVID-19 } \\
\text { patients, 224/ } \\
399 \text { Influenza-A } \\
\text { viral such as H1N1, } \\
\text { H7N9 }\end{array}$ & $\begin{array}{l}2 \mathrm{~d} \text { or } 3 \mathrm{D} \text { deep } \\
\text { learning } \\
\text { algorithm done }\end{array}$ & $\begin{array}{l}\text { ResNet for } \\
\text { feature } \\
\text { extraction }\end{array}$ & $\begin{array}{l}\text { AUC } 0.966 \text { for } \\
\text { COVID-19 positive and } \\
\text { negative, sensitivity } \\
98.2 \% \text {, and specificity } \\
92.2 \%\end{array}$ \\
\hline 10 & $\begin{array}{l}\text { April } \\
2020\end{array}$ & $\begin{array}{l}\text { Joel et al. } \\
\text { [41] }\end{array}$ & $\begin{array}{l}\text { Transmission } \\
\text { stochastic } \\
\text { model used to } \\
\text { parametrize to } \\
\text { the } \\
\text { coronavirus }\end{array}$ & $\begin{array}{l}\text { Dataset } \\
\text { available on } \\
\text { GitHub }\end{array}$ & $\begin{array}{l}24550 \text { cases, } \\
190 \text { infected } \\
490 \text { deaths }\end{array}$ & $\begin{array}{l}\text { coronavirus } \\
\text { outbreak } \\
\text { controlling of } \\
\text { feasibility }\end{array}$ & $\begin{array}{l}\text { Stochastic } \\
\text { parametrize }\end{array}$ & $\begin{array}{l}\text { Stochastic transmission } \\
2.5,20 \text { cases, and } 15 \% \text { of } \\
\text { transmission before } \\
\text { symptom }\end{array}$ \\
\hline 11 & $\begin{array}{l}\text { May } \\
2020\end{array}$ & $\begin{array}{l}\text { Muhammad } \\
\text { et al. [42] }\end{array}$ & $\begin{array}{l}\text { qRT-PCR, and } \\
\text { CT analysis }\end{array}$ & $\begin{array}{l}\text { RT-PCR } \\
\text { and, CT scan }\end{array}$ & $\begin{array}{l}\text { Total subjects } 1275 \text {, } \\
\text { male patients } 599, \\
\text { and } \\
\text { female patients } 676\end{array}$ & $\begin{array}{l}\text { Review of qtr- } \\
\text { PCR, and CT } \\
\text { scan methods }\end{array}$ & $\begin{array}{l}\text { Higher } \\
\text { bilateral lobe } \\
(51.4 \%) \text { than } \\
\text { single lobe } \\
(21.5 \%) \text { in } \\
\text { coronavirus } \\
\text { infected } \\
\text { patients }\end{array}$ & $\begin{array}{l}\text { qRT-PCR showed } 81.3 \% \\
\text { positive, } \\
\text { abnormal CT scan showed } \\
\text { in } 89.8 \% \text { patient }\end{array}$ \\
\hline
\end{tabular}


The literature review implies the following things: First, common symptoms shown by coronavirus patients around the globe include fever and dry cough. Second, death rates were higher in cases where patients had predominant chronic diseases, like cancer or old age patients. Third, the detection methods that performed best in the COVID-19 cases include machine learning, deep learning, and CNN which show higher accuracy levels. These frameworks outperform the results obtained after molecular biology techniques. The next section determines the method we used to detect coronavirus patients according to their symptoms with utilization of LR, KNN, DT, NB, and SVM. The results would help the healthcare sector in decision making especially the countries where the disease is expected to affect greatly [43].

\section{Research Methodology}

Machine learning classification algorithms take up data to process, classify, or predict. The flow of the process involves pre-processing which includes data cleaning, data transformation, and feature selection, followed by the application of machine learning algorithms.

\subsection{Data Collection and Pre-Processing}

Our study presented in this paper is based on publicly available databases. The dataset is obtained from the Israeli government website and is accessible worldwide, https://data.gov.il/dataset/covid-19/resource/ d337959a-020a-4ed3-84f7-fca182292308. Such type of datasets are also used by several other research publications [6]. Although the website is constantly updated with the latest data, we used a dataset from 15/12/2020 till 21/01/2021. A total of 1,048,576 entries of patient records are contained in the dataset, containing symptoms and actual results of the potential COVID-19 patients. The columns are as follows: test_date, cough, fever, sore_throat, shortness of breath, head_ache, corona_result, age_60_and_above, gender, and test_indication.

Firstly, the data is obtained from the source and analyzed. However, the data obtained is noisy and needs to be handled, otherwise, it could be misinterpreted, which could result in erroneous outcomes of the algorithm. The missing values are dropped and the data types of the required features are transformed. For the analysis, the features contained in the file and their correlation is examined. The features are shortlisted by peer-review to obtain the set of features around which the model will be revolved. The correlation between the selected variables can be seen in the above Tab. 3 .

Table 3: Correlation table

\begin{tabular}{llllll}
\hline & Cough & Fever & Sore_throat & Head_ache & Corona_result \\
\hline Cough & 1.000000 & 0.333990 & 0.286263 & 0.350175 & 0.384887 \\
Fever & 0.333990 & 1.000000 & 0.198695 & 0.291549 & 0.323162 \\
Sore_throat & 0.286263 & 0.198695 & 1.000000 & 0.316232 & 0.255587 \\
Head_ache & 0.350175 & 0.291549 & 0.316232 & 1.000000 & 0.387503 \\
Corona_result & 0.384887 & 0.323162 & 0.255587 & 0.387503 & 1.000000 \\
\hline
\end{tabular}

\subsection{Machine Learning Models, Technology, and Evaluation Metrics}

Jupiter notebook is incorporated for simulation. The model formed is an intelligent system that is empowered by machine learning techniques' implementation on the pre-processed dataset. Moreover, several statistical measures are incorporated for the evaluation of the prediction of the suggested model. The algorithms applied are as follows: 
- Logistic regression

- KNeighbors classifier

- Decision tree

- Naïve bayes

- Support vector machine

The accuracy of a machine learning algorithm is the way to evaluate how exactly the algorithm classifies a data point. To be precise, it is calculated by the number of true positives and true negatives divided by the total number including true positives, false positives, true negatives, and false negatives. The equation below shows how accuracy is calculated.

Accuracy $=\frac{\mathrm{TP}+\mathrm{TN}}{\mathrm{TP}+\mathrm{TN}+\mathrm{FP}+\mathrm{FN}}$

Moreover, accuracy is used along with the calculation of precision and recall. The precision is calculated by the total number of true positives divided by the sum of true positives and false positives. Whereas, the recall is measured by the true positives divided by the sum of true positives and false negatives. The calculation is further demonstrated by the following equations:

Precision $=\frac{\mathrm{TP}}{\mathrm{TP}+\mathrm{FN}}$

Recall $=\frac{\mathrm{TP}}{\mathrm{TP}+\mathrm{FN}}$

Machine learning has an essential task of performance measurement of the applied classifiers. The performance of the algorithms is visualized by the corresponding confusion matrices.

A confusion matrix is used in various machine learning problems, including the statistical classification problems being solved by supervised learning. The confusion matrix is based on true positive (TP), true negative (TN), false positive (FP), and false-negative (FN) values. TP is the instance where the model correctly identifies the positive class. TN is the outcome where models correctly identities the actual negative class. FP is the outcome at which the model incorrectly predicts the class when actually it is not present. Lastly, FN is the outcome where the model does not identify even in its presence. Tab. 4 above shows how a confusion matrix is plotted.

Table 4: Confusion matrix

\begin{tabular}{lll}
\hline & Predicted 0 & Predicted 1 \\
\hline Actual 0 & True Negative (TN) & False Positive (FP) \\
Actual 1 & False Negative (FN) & True Positive (TP) \\
\hline
\end{tabular}

Moreover, a classification report is used to find out the quality of predictions corresponding to each classification algorithm. The metrics included in the report are precision, recall, f1-score, and support. Precision is the measure of the number of times the model identified an instance positive, which was actually positive as well. It can be calculated by the total positives divided by the sum of total positives and false negatives. The equation below shows how precision is calculated. 
Precision $=\frac{\mathrm{TP}}{\mathrm{TP}+\mathrm{FN}}$

The recall is the fraction of positive which the classifier has identified correctly. It can be calculated by the total positives divided by the sum of total positives and false negatives. The following equation shows the method of calculation of recall.

Recall $=\frac{\mathrm{TP}}{\mathrm{TP}+\mathrm{FN}}$

Additionally, the classification report consists of F1-score which is the weighted harmonic mean of precision and recall. An fl-score of 1.0 is considered best and 0.0 is considered worse. This score is usually used to compare the classifier models, not the global accuracy. The equation below shows the method of calculating f1-score.

$F 1$ Score $=\frac{2 *(\text { Recall } * \text { Precision })}{\text { Recall }+ \text { Precision }}$

Lastly, the support is the total number of actual occurrences of the class in the dataset. The next section explains the obtained results concerning each incorporated classifier.

\section{Results and Discussion}

Machine learning classifiers used in this study incorporate supervised learning to solve binary classification problems. The TP value of the confusion matrix refers to the number of patients that truly have COVID-19 and the corresponding classifier identifies it correctly. The FP value refers to the patient count that actually doesn't have COVID-19 but the classifier erroneously identifies them with the disease. The TN is the number of patients in the dataset that actually don't have COVID-19 and the classifier also identifies them correctly. Lastly, the FN is the number of patients that truly have COVID-19, but the model erroneously identifies them as not having the illness. Below are the results of each classifier along with their accuracies, confusion matrices, and classification report.

\subsection{KNeighbors Findings}

The accuracy obtained with the KNeighbors is 93.53890966265863 .

\subsubsection{Confusion Matrix}

The following Tab. 5 demonstrates the TP, TN, FP, and FN values obtained through KNeighbors algorithm.

Table 5: Confusion matrix of KNeighbors

\begin{tabular}{lll}
\hline & Predicted 0 & Predicted 1 \\
\hline Actual 0 & 177902 & 2658 \\
Actual 1 & 10163 & 7711 \\
\hline
\end{tabular}

\subsubsection{Classification Report}

The following Tab. 6 shows the findings in terms of precision, recall, fl-score, and support value corresponding to the KNeighbors algorithm. 
Table 6: Classification report of KNeighbors

\begin{tabular}{lllll}
\hline & Precision & Recall & f-1 score & Support \\
\hline 0 & 0.95 & 0.99 & 0.97 & 180560 \\
1 & 0.74 & 0.43 & 0.55 & 17874 \\
Macro average & 0.84 & 0.71 & 0.76 & 198434 \\
Weighted average & 0.93 & 0.94 & 0.93 & 198434 \\
\hline
\end{tabular}

\subsection{Logistic Regression Findings}

The accuracy obtained with the logistic regression is 92.76787244121472 .

\subsubsection{Confusion Matrix}

The following Tab. 7 shows a confusion matrix of logistic regression findings, it shows high true positive (TP) for class 0 which are the instances where the model correctly identified patients with coronavirus from the dataset.

Table 7: Confusion matrix of logistic regression

\begin{tabular}{lll}
\hline & Predicted 0 & Predicted 1 \\
\hline Actual 0 & 178950 & 1610 \\
Actual 1 & 12741 & 5133 \\
\hline
\end{tabular}

\subsubsection{Classification Report}

The following Tab. 8 shows the detailed performance report of logistic regression in terms of its precision, recall, $\mathrm{f}-1$ score, and support value.

Table 8: Classification report of logistic regression

\begin{tabular}{lllll}
\hline & Precision & Recall & f-1 score & Support \\
\hline 0 & 0.93 & 0.99 & 0.96 & 180560 \\
1 & 0.76 & 0.29 & 0.42 & 17874 \\
Macro average & 0.85 & 0.64 & 0.69 & 198434 \\
Weighted average & 0.92 & 0.93 & 0.91 & 198434 \\
\hline
\end{tabular}

\subsection{Decision Tree Findings}

The accuracy obtained with the decision tree is 93.69815656591108 .

\subsubsection{Confusion Matrix}

The following Tab. 9 shows the confusion matrix of the decision tree algorithm for the classes 0 and 1 which are corona negative and corona positive patients correspondingly. 
Table 9: Confusion matrix of decision tree

\begin{tabular}{lll}
\hline & Predicted 0 & Predicted 1 \\
\hline Actual 0 & 177773 & 2787 \\
Actual 1 & 9718 & 8156 \\
\hline
\end{tabular}

\subsubsection{Classification Report}

The following Tab. 10 shows the classification report stating precision, recall, f-1 score, and support of decision tree findings. It can be seen that the outcomes of class 0 (corona negative) are much better.

Table 10: Classification report of decision tree

\begin{tabular}{lllll}
\hline & Precision & Recall & f-1 score & Support \\
\hline 0 & 0.95 & 0.98 & 0.97 & 180560 \\
1 & 0.75 & 0.46 & 0.57 & 17874 \\
Macro average & 0.85 & 0.72 & 0.77 & 198434 \\
Weighted average & 0.93 & 0.94 & 0.93 & 198434 \\
\hline
\end{tabular}

\subsection{Naive Bayes Model Findings}

The accuracy obtained with the naïve bayes is 93.69815656591108 .

\subsubsection{Confusion Matrix}

The following Tab. 11 shows the confusion matrix stating the values TP, TN, FP, and FN of naïve bayes model. The TP values for class 0 (corona negative) are high.

Table 11: Confusion matrix naive bayes

\begin{tabular}{lll}
\hline & Predicted 0 & Predicted 1 \\
\hline Actual 0 & 177773 & 2787 \\
Actual 1 & 9718 & 8156 \\
\hline
\end{tabular}

\subsubsection{Classification Report}

The following Tab. 12 shows the details of precision, recall, $\mathrm{f}-1$ score, and support values for naïve bayes algorithm.

Table 12: Classification report of naive bayes

\begin{tabular}{lllll}
\hline & Precision & Recall & f-1 score & Support \\
\hline 0 & 0.95 & 0.98 & 0.97 & 180560 \\
1 & 0.75 & 0.46 & 0.57 & 17874 \\
Macro average & 0.85 & 0.72 & 0.77 & 198434 \\
Weighted average & 0.93 & 0.94 & 0.93 & 198434 \\
\hline
\end{tabular}




\subsection{Support Vector Machine}

The accuracy obtained with the SVM is 93.57418587540441.

\subsubsection{Confusion Matrix}

The following Tab. 13 shows the confusion matrix for the support vector machine algorithm.

Table 13: Confusion matrix of SVM

\begin{tabular}{lll}
\hline & Predicted 0 & Predicted 1 \\
\hline Actual 0 & 177914 & 2646 \\
Actual 1 & 10105 & 7769 \\
\hline
\end{tabular}

\subsubsection{Classification Report}

The following Tab. 14 shows the report containing values of precision, recall, $f-1$ score, and support for SVM.

Table 14: Classification report of SVM

\begin{tabular}{lllll}
\hline & Precision & Recall & f-1 score & Support \\
\hline 0 & 0.95 & 0.99 & 0.97 & 180560 \\
1 & 0.75 & 0.43 & 0.55 & 17874 \\
Macro average & 0.85 & 0.71 & 0.76 & 198434 \\
Weighted average & 0.93 & 0.94 & 0.93 & 198434 \\
\hline
\end{tabular}

The following Tab. 15 compares the performance of the five incorporated models according to the obtained accuracies:

Table 15: Models accuracy

\begin{tabular}{ll}
\hline Model & Accuracy Score \\
\hline Naïve bayes & $93.70 \%$ \\
Decision tree & $93.70 \%$ \\
Support vector machine & $93.60 \%$ \\
KNeighbors & $93.50 \%$ \\
Logistic Regression & $92.80 \%$ \\
\hline
\end{tabular}

Since the precision and recall are high for class 0 in all the 5 classifiers, we deduce that the class is perfectly handled by the classifiers. The comparison of all the applied algorithms with respect to accuracy scores show that Naïve bayes and Decision tree outperform the remaining algorithms which are support vector machine, KNeighbors, and logistic regression in the determination of COVID-19 based on significant features from the symptoms. 
The following Tab. 16 illustrates the performance evaluation with a previously published approach empowered by deep learning with train-test splits approaches [47]. As shown in the table, our proposed model that incorporates machine learning algorithms outperforms the other deep learning algorithm in terms of accuracy.

Table 16: Performance evaluation with the previous approach

\begin{tabular}{lll}
\hline & Previously Deep Learning Model [47] & Proposed Machine Learning model \\
\hline Accuracy & CNNLSTM 92.30\% LSTM 90.34\% & Naïve bayes 93.70\% Decision Tree 93.70\% \\
\hline
\end{tabular}

From the study, we determine that supervised machine learning algorithms can be utilized for the prediction of COVID-19 in patients with potential symptoms of this disease. For evaluation of the models, we have used the metrics of accuracy. Accuracy is the fraction of predictions that the model got correct. By comparing the obtained results critically, we determine that logistic regression performs most inexact with an accuracy of $92.80 \%$ whereas, NB and DT show highest accuracy of $93.70 \%$.

\section{Conclusion}

This study presents the accuracy and performance of the machine learning classifiers: DT, KNN, SVM, LR, and NB algorithms to determine the presence of COVID-19 in potential patients. We studied the impact of this illness on different age groups, genders, and people having previous medical conditions. A large dataset which contains the details of the date on which the patient was tested, presence of cough, fever, sore throat, and headache. The outcome of coronavirus test conducted for patient, information of the age of patient, gender, and another indicator such as contact of the patient with another coronavirus patient was analyzed and pre-processed. A vast range of models and algorithms for data analysis and visualization were considered and examined. However, after comparison and peer review, we selected the above-mentioned algorithms for our study. The comparison between their results shows that the NB, and DT demonstrates the highest performance in terms of accuracy whereas, LR demonstrates the least.

This research aims to assist future researchers in examining the machine learning approaches to solve COVID-19 problems and to determine whether the patient is sick with this particular illness. Moreover, this research can be extended in future to address relevant problems of other diseases and act accordingly in case of potential pandemic.

Acknowledgement: Thanks to our families and colleagues who supported us morally.

Funding Statement: The author(s) received no specific funding for this study.

Conflict of Interests: The authors declare that they have no conflicts of interest to report regarding the present study.

\section{References}

[1] V. K. Deshwal, "COVID-19: A comparative study of asian, european, american continent," International Journal of Scientific Research and Engineering Development, vol. 3, no. 2, pp. 436-440, 2020.

[2] Y. A. Alrazaq, A. M. Alajlani, D. Alhuwail, J. Schneider, S. A.Kuwari et al., "Artificial intelligence in the fight against COVID-19: Scoping review," Journal of Medical Internet Research, vol. 22, no. 12, pp. 1-18, 2020.

[3] X. Wang, X. Deng, Q. Fu, Q. Zhou, Feng et al., "A weakly-supervised framework for covid-19 classification and lesion localization from chest ct," IEEE Transactions on Medical Imaging, vol. 39, no. 8, pp. 2615-2625, Aug. 2020. 
[4] R. Zagrouba, M. A. Khan, M. A. Saleem, M. F. Mushtaq et al., "Modelling and simulation of COVID-19 outbreak prediction using supervised machine learning," Computers, Materials \& Continua, vol. 66, no. 3, pp. 2397-2407, 2021.

[5] L. J. Muhammad, E. A. Algehyne, S. S. Usman, A. Ahmad, C. Chakraborty et al., "Supervised machine learning models for prediction of COVID-19 infection using epidemiology dataset," Springer Nature: SN Computer Science, vol. 2, no. 11, pp. 1-13, 2021.

[6] M. A. Quiroz-Juarez, A. T. Gomez, I. H. Ulloa, R. D. J. L. Montiel et al., "Identification of high-risk COVID-19 patients using machine learning," MedRxiv, vol. 66, no. 3, pp. 1-10, 2021.

[7] I. Arpaci, S. Huang and M. A. Emran, "Predicting the COVID-19 infection with fourteen clinical features using machine learning classification algorithms," Multimedia Tools \& Applications, vol. 1, no. 1, pp. 1-15, 2021.

[8] N. S. Punn, S. K. Sonbhadra and S. Agarwal, "COVID-19 epidemic analysis using machine learning and deep learning algorithms," Health Informatics, vol. 1, no. 1, pp. 1-10, 2020.

[9] A. Alimadadi, S. Aryal, I. Manandhar, P. B. Munroe, B. Joe et al., "Artificial intelligence and machine learning to fight COVID-19," Physiological Genomics, vol. 52, no. 4, pp. 200-202, Apr. 2020.

[10] A. Albahri and R. A. Hamid, "Role of biological data mining and machine learning techniques in detecting and diagnosing the novel coronavirus: A systematic review," Journal of Medical Systems, vol. 44, no. 7, pp. 1-10, 2020.

[11] M. Pourhomayoun and M. Shakibi, "Predicting mortality risk in patients with COVID-19 using artificial intelligence to help medical decision-making," Health Informatics, vol. 1, no. 1, pp. 1-10, 2020.

[12] A. Erraissi, M. Azouazi, A. Belangour and M. Banane, "Machine learning model to predict the number of cases contaminated by COVID-19," International Journal of Computing and Digital Systems, vol. 9, pp. 1-11, 2020.

[13] S. F. Ardabili, "COVID-19 outbreak prediction with machine learning," Specialized Research Networks Journal, vol. 1, pp. 1-11, 2020.

[14] Q. Li, "Early transmission dynamics in wuhan, china, of novel coronavirus-infected pneumonia," New England Journal of Medicine, vol. 382, no. 13, pp. 1199-1207, Mar. 2020.

[15] C. Huang, "Clinical features of patients infected with 2019 novel coronavirus in wuhan, china," Lancet, vol. 395, no. 10223, pp. 497-506, Feb. 2020.

[16] Y. He, H. Yu, E. Ong, Y. Wang, L. Huffman et al., "Cid, a community-based ontology for coronavirus disease knowledge and data integration, sharing, and analysis," Scientific Data, vol. 7, no. 1, pp. 1-5, 2020.

[17] S. Li, Y. Wang, J. Xue, N. Zhao and T. Zhu, "The impact of COVID-19 epidemic declaration on psychological consequences: A study on active weibo users," International Journal of Environmental Research and Public Health, vol. 17, no. 6, pp. 2032, Mar. 2020.

[18] J. Wu, "Clinical characteristics of imported cases of coronavirus disease 2019 COVID-19 in jiangsu province: A multicenter descriptive study," Clinical Infectious Diseases, vol. 1, pp. 1-9, Feb. 2020.

[19] L. Zhang, "Clinical characteristics of COVID-19 infected cancer patients: A retrospective case study in three hospitals within wuhan, china," Annals of Oncology, vol. 31, no. 7, pp. 894-901, Jul. 2020.

[20] J. Yang, "Prevalence of comorbidities and its effects in patients infected with SARS-CoV-2: A systematic review and meta-analysis," International Journal of Infectious Diseases, vol. 94, pp. 91-95, May 2020.

[21] Z. Wu and J. M. McGoogan, "Characteristics of and important lessons from the coronavirus disease 2019 (COVID-19) outbreak in china," JAMA Network, vol. 323, no. 13, pp. 1239, Apr. 2020.

[22] H. Shi, "Radiological findings from 81 patients with COVID-19 pneumonia in wuhan, china: A descriptive study," Lancet Infectious Diseases, vol. 20, no. 4, pp. 425-434, Apr. 2020.

[23] A. Polacco and K. Backes, "The amazon go concept: implications, applications, and sustainability," Journal of Business and Management, vol. 24, no. 1, pp. 79-90, 2020.

[24] Y. Liu, A. A. Gayle, A. W. Smith and J. Rocklöv, "The reproductive number of COVID-19 is higher compared to SARS coronavirus," Journal of Travel Medicine, vol. 27, no. 2, pp. 0-21, Mar. 2020.

[25] Q. Ruan, K. Yang, W. Wang, L. Jiang and J. Song, "Correction to: Clinical predictors of mortality due to COVID-19 based on an analysis of data of 150 patients from Wuhan, China," Intensive Care Med, vol. 46, no. 6, pp. 1294-1297, Jun. 2020. 
[26] L. Mao, "Neurologic manifestations of hospitalized patients with coronavirus disease 2019 in Wuhan, China," JAMA Neurology, vol. 77, no. 6, pp. 683-690, 2019.

[27] T. Ai, "Correlation of chest CT and RT-PCR testing in coronavirus disease 2019 (COVID-19) in China: A report of 1014 cases," Radiology, vol. 296, no. 2, pp. 32-40, Feb. 2020.

[28] L. V. Cuong, "The first vietnamese case of COVID-19 acquired from china," Lancet Infectious Diseases, vol. 20, no. 4, pp. 408-409, Apr. 2020.

[29] J. Wu, "Clinical characteristics of imported cases of coronavirus disease 2019 (COVID-19) in Jiangsu Province," Clinical Infectious Diseases, vol. 71, no. 15, pp. 706-712, Feb. 2020.

[30] Z. Hu, "Clinical characteristics of 24 asymptomatic infections with COVID-19 screened among close contacts in Nanjing," China Science China Life Sciences, vol. 63, no. 5, pp. 706-711, May 2020.

[31] M. Shen, "Recent advances and perspectives of nucleic acid detection for coronavirus," Journal of Pharmaceutical Analysis, vol. 10, no. 2, pp. 97-101, Apr. 2020.

[32] P. K. Sethy and S. K. Behera, "Detection of coronavirus disease (COVID-19) based on deep features," Engineering, vol. 2, pp. 1-15, Mar. 2020.

[33] M. N. Mohammed, H. Syamsudin, S. AlZubaidi, R. Ramli and E. Yusuf, "Novel COVID-19 detection and diagnosis system using IoT based smart helmet," International Journal of Psychosocial Rehabilitation, vol. 24, no. 7, pp. 2296-2303, 2020.

[34] M. Farooq and A. Hafeez, "Covid-resNet: A deep learning framework for screening of COVID-19 from radiographs," arXiv, vol. 1, pp. 1-15, Mar. 2020.

[35] I. D. Apostolopoulos and T. A. Mpesiana, "COVID-19: Automatic detection from X-ray images utilizing transfer learning with convolutional neural networks," Physical and Engineering Sciences in Medicine, vol. 43, pp. 635-640, April 2020.

[36] B. Ghoshal and A. Tucker, "Estimating uncertainty and interpretability in deep learning for coronavirus (COVID-19) Detection," arXiv, vol. 2, pp. 1-11, Mar. 2020.

[37] C. Butt, J. Gill, D. Chun and B. A. Babu, "Deep learning system to screen coronavirus disease 2019 pneumonia," Applied Intelligence, vol. 1, pp. 1-7, Apr. 2020.

[38] B. Cao, "A trial of lopinavir-rionavir in adults hospitalized with severe COVID-19," Physical and Engineering Sciences in Medicine, vol. 382, no. 19, pp. 1787-1799, May 2020.

[39] Y. Liu, A. Gayle, A. W. Smith and J. Rocklöv, "The reproductive number of COVID-19 is higher compared to SARS coronavirus," Journal of Travel Medicine, vol. 27, no. 2, pp. taaa021, Mar. 2020.

[40] Q. Wang, S. Xie, Y. Wang and D. Zeng, "Survival-convolution models for predicting COVID-19 cases and assessing effects of mitigation strategies," Frontiers in Public Health, vol. 3, no. 8, pp. 325, 2020.

[41] J. Hellewell, "Feasibility of controlling COVID-19 outbreaks by isolation of cases and contacts," Lancet Global Health, vol. 8, no. 4, pp. e488-e496, Apr. 2020.

[42] A. Narin, C. Kaya and Z. Pamuk, "Automatic detection of coronavirus disease (COVID-19) using x-ray images and deep convolutional neural networks," arXiv, vol. 2, pp. 30-45, Mar. 2020.

[43] K. Abid, Y. A. Bari, M. Younas, S. T. Javaid and A. Imran, "Progress of COVID-19 epidemic in Pakistan," Asia Pacific Journal of Public Health, vol. 32, no. 4, pp. 154-156, May 2020.

[44] M. R. Naqvi, M. A. Jaffar, M. Aslam, S. K. Shahzad, M. W. Iqbal et al., "Importance of big data in precision and personalized medicine," International Congress on Human-Computer Interaction, Optimization and Robotic Applications (HORA), Anarka,Turkey, vol. 1, no. 1, pp. 1-6, 2020.

[45] A. M. Khanday, U. D. Rabani and S. T. Khan, "Machine learning based approaches for detecting COVID-19 using clinical text data," International Journal of Information Technology, vol. 1, no. 1, pp. 1-9, 2020.

[46] W. Kai, S. Zhao, Y. Liao, T. Zhao, X. Wang et al., "Estimating the serial interval of the novel coronavirus disease (COVID-19) based on the public surveillance data in shenzhen, china from january 19 to february 22, 2020," Transboundary and Emerging Diseases, vol. 1, no. 1, pp. 1-9, 2020.

[47] T. B. Alakus and I. Turkoglu, "Comparison of deep learning approaches to predict COVID-19 infection," Chaos Solitons \& Fractals, vol. 140, pp. 110-120, 2020. 